Case Report

\title{
Acquired Hemophilia A: A Permanent Challenge for All Physicians
}

\author{
Knut M. Nowak ${ }^{1}$, Alexander Carpinteiro ${ }^{2}$, Cynthia Szalai ${ }^{3}$ and Fuat H. Saner ${ }^{1, *(D)}$ \\ 1 Department of General, Visceral- and Transplant Surgery, Medical Center University Duisburg-Essen, \\ 45147 Essen, Germany; knut.nowak@uk-essen.de \\ 2 Department of Hematology and Stem Cell Transplantation, Medical Center University Duisburg-Essen, \\ 45147 Essen, Germany; alexander.carpinteiro@uk-essen.de \\ 3 Department of Anesthesiology and Critical Care, Medical Center University Duisburg-Essen, \\ 45147 Essen, Germany; cynthia.szalai@uk-essen.de \\ * Correspondence: fuat.saner@uni-due.de; Tel.: +49-201-723-84008; Fax: +49-201-723-1145
}

Citation: Nowak, K.M.; Carpinteiro, A.; Szalai, C.; Saner, F.H. Acquired

Hemophilia A: A Permanent

Challenge for All Physicians.

Medicines 2022, 9, 21. https://

doi.org/10.3390/medicines 9030021

Academic Editor: William Cho

Received: 17 December 2021

Accepted: 1 March 2022

Published: 2 March 2022

Publisher's Note: MDPI stays neutral with regard to jurisdictional claims in published maps and institutional affiliations.

Copyright: (c) 2022 by the authors. Licensee MDPI, Basel, Switzerland. This article is an open access article distributed under the terms and conditions of the Creative Commons Attribution (CC BY) license (https:// creativecommons.org/licenses/by/ $4.0 /)$.

\begin{abstract}
Acquired hemophilia A (AHA) is a rare disease with a prevalence in Europe of 1.5 per million. This diagnosis is significantly delayed in about one-third of all cases, leading to deferred treatment. The main signs of AHA are spontaneous bleeding seen in about two-thirds of all patients. AHA can be lethal in $20 \%$ of all symptomatic cases. This patient population's main standard laboratory finding is a prolonged aPTT (activated prothrombin Time) with otherwise normal coagulation results. In addition, antibodies against FVIII (in Bethesda Units) and a quantitative reduction of FVIII activity are necessary to confirm AHA. The therapy of acute bleeding related to AHA is based on the following main principles: Pharmacologic control of the bleeding is of absolute importance. It can be achieved by administering either recombinant activated FVIIa "bypass therapy"; activated prothrombin complex; or Emicizumab, a bispecific monoclonal antibody. Eradication of the FVIII antibodies should be initiated simultaneously. The combination of steroids with cyclophosphamide leads to the highest eradication rates. Causes of AHA may be related to neoplasms, autoimmune diseases, and pregnancy. We report on a patient who underwent four surgical procedures before the diagnosis of AHA was established.
\end{abstract}

Keywords: bleeding; acquired hemophilia A (AHA); recombinant activated factor VIIa

\section{Case Report}

We report on a 68-year-old female patient who developed a retroperitoneal hematoma $(12 \times 13 \mathrm{~cm})$ after falling at home. The patient underwent multiple surgeries, including abdominal packing and depacking of towels. Despite hemostasis treatment consisting of fresh frozen plasma and Prothrombin-complex (PCC) transfusions, surgical bleeding could not be controlled. The patient was then referred to our facility for further treatment.

At the time of admission, the patient was intubated and ventilated using a bilevel positive airway pressure mode with the following parameters: an inspired Oxygen 50\%, positive end-expiratory pressure $12 \mathrm{mbar}$, inspiratory pressure $30 \mathrm{mbar}$, and lung compliance of $35 \mathrm{~mL} / \mathrm{mbar}$. The patient had an ARDS II according to the Berlin classification (bilateral occupation of both lungs and Horowitz index $148 \mathrm{mmHg}$ ) [1].

The standard coagulation parameters showed an isolated aPTT prolongation $(72.7 \mathrm{~s})$, while PT/INR and platelets were in the normal range. ROTEM analysis showed a prolonged clotting time in the INTEM assay (see Figure 1). Isolated prolongation of the aPTT; patient age; and the lack of bleeding history together with the acute, spontaneous bleeding propensity suggested the suspicion for AHA. The factor VIII (FVIII) activity was not detectable ( $<1 \%$ activity). A simultaneous assessment of the inhibitor against FVIII was positive. The Bethesda Units (BE) were 15. 


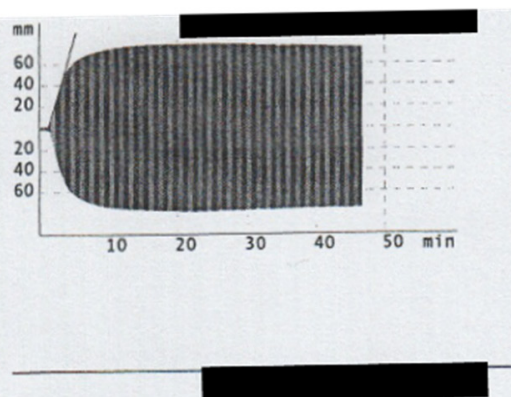

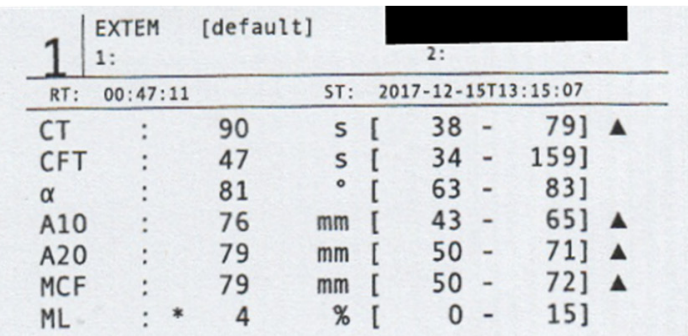
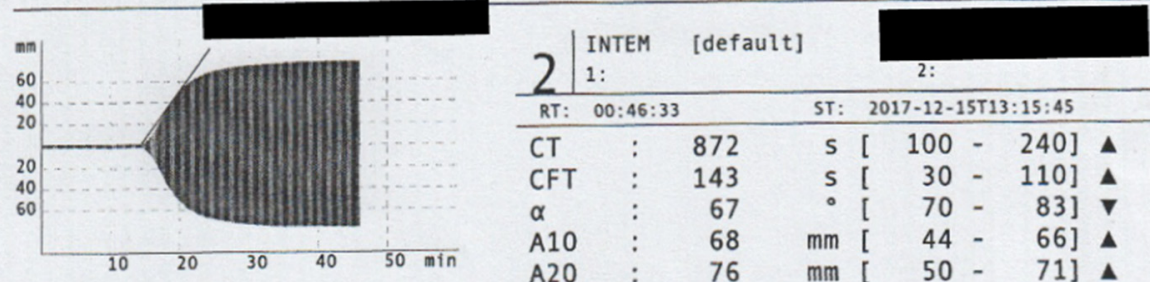

CFT : 143 S [ $30-110] \Delta$

$\alpha \quad: \quad 67 \quad \circ\left[\begin{array}{ll}70-83] \nabla \\ \hline\end{array}\right.$

A10 : $68 \mathrm{~mm}[44-66]$ A

A20 : 76 mm [ $50-71]$

$\begin{array}{lllll}\text { A20 } & & 76 & \mathrm{~mm}[ & 50-71] \\ \text { MCF } & * 77 & \mathrm{~mm}[50-72]\end{array}$

ML : * 0 \% [ 0 - 15]

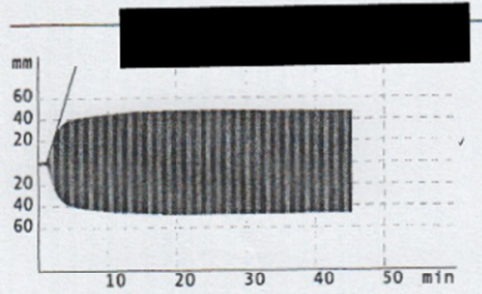

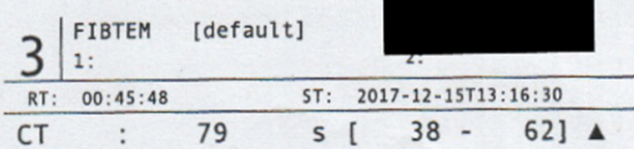

CFT : 49 S

$\alpha \quad: \quad 80$

A10 : 46 mm [ $7-23]$ A

A20 : $48 \mathrm{~mm}[8-24]$ A

MCF : 48 mm [ $9-25]$ A

ML : * 2 \%

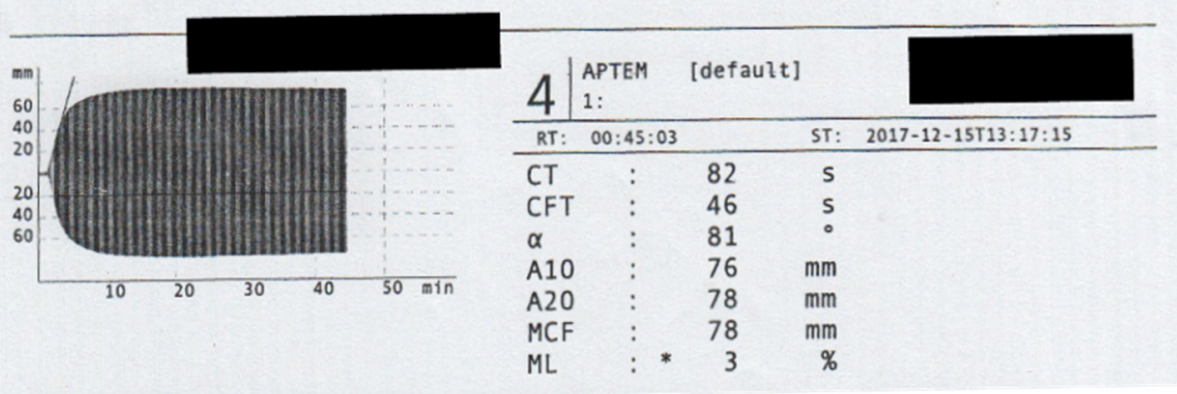

Figure 1. Rotem assessment on Admission. The Rotem analyses showed a significant prolongation of the clotting time (CT) in the INTEM channel. To prevent Heparin administration, we did not conduct a HEPTEM assay. The maximum clot firmness (MCF) in the EXTEM assay $(79 \mathrm{~mm})$ is mainly caused by the extremely high fibrin polymerization recorded in FIBTEM channel (MCF $=48 \mathrm{~mm})$.

Emergency relaparotomy was indicated as the patient's abdomen was still packed even after bleeding was controlled. Recombinant activated FVII (rFVIIa; NovoSeven ${ }^{\circledR}$ ) was administered in a dose of $90 \mu \mathrm{g} / \mathrm{kg}$ body weight. Due to the half-life of rFVIIa of $1.5 \mathrm{~h}$, the same dose was readministered every $3 \mathrm{~h}$ perioperatively for the next $72 \mathrm{~h}$ (cumulative $48 \mathrm{mg}$ per day).

After $72 \mathrm{~h}$, the dose of rFVIIa was halved, and application intervals were increased to $6 \mathrm{~h}$. On the 8th day of admission, infusion of rFVIIa was no longer necessary. Once the diagnosis of AHA was confirmed, eradication therapy was started with prednisone (70 mg/day corresponding to $1 \mathrm{mg} / \mathrm{kg}$ body weight) and cyclophosphamide (100 mg/day). After this treatment, there was a significant increase in FVIII from $<1 \%$ to $9.7 \%$ on the 20th day after the start of eradication therapy (last value was measured 4 weeks after admission: $123.4 \%$ ). As an adjunct treatment, the patient received tranexamic acid $(3 \times 1 \mathrm{~g}$ p.o. $)$ until the FVIII was increased to $>5 \%$. When FVIII activity was $>20 \%$, a percutaneous tracheostomy was performed to facilitate prolonged ventilation. The patient was successfully weaned 
from the respirator after 109 days when FVIII activity was $>20 \%$. There was a steady improvement in the general condition.

After a total hospital stay of 145 days (118 days at intensive care unit, 27 days in intermediate care unit, and $2321 \mathrm{~h}$ of ventilation), the patient recovered adequately from her underlying condition to be discharged for follow-up treatment. The time course of the interventions in the first 6 weeks is shown in Figure 2.

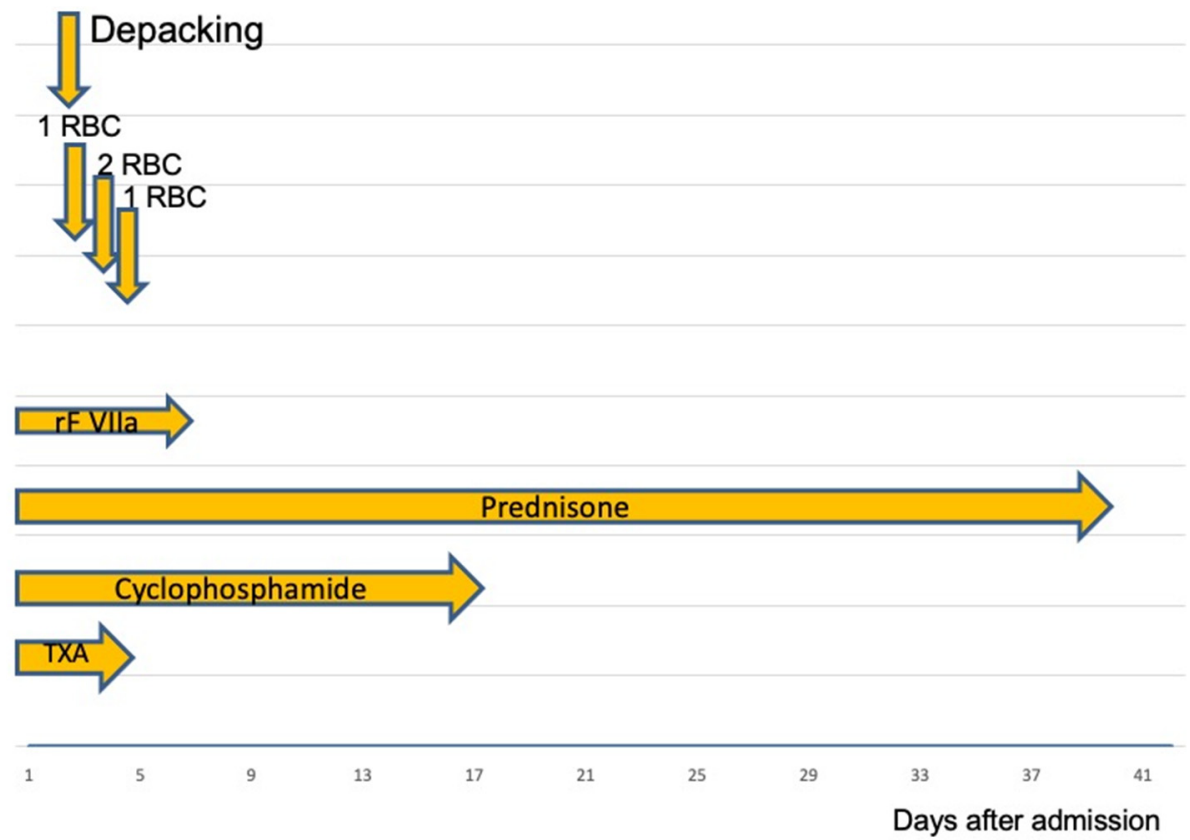

Figure 2. RBC: packed Red Blood Cells; rFVIIa: recombinant Factor VIIa, TXA: Tranexamic acid. After successful coagulation management, the bleeding was stopped. On the second admission day, abdominal packs were removed. During the initial 4 days, the patient received a total of four units of RBCs. Following surgery, the dose of rFVIIa was reduced and then stopped after 3 days.

\section{Discussion}

\subsection{Epidemiology}

AHA should always be considered with the occurrence of spontaneous retroperitoneal bleeding and a negative bleeding history, especially in patients between the 6th and 8th decades of life [2]. Due to its rare occurrence, diagnosis and treatment are delayed as in the presented case.

The incidence of AHA is estimated as 1.5 cases $/ 1,000,000$ population in Europe [3]. Knoebl et al. [3] evaluated the European Acquired Hemophilia Registry (EACH2), which represented data from 13 European countries, including 117 centers and 501 patients. At the time of diagnosis, the median age was 73.9 years. In $51.9 \%$ of patients, AHA was not triggered; in $11.8 \%$ of the cases, the diagnosis was associated with either tumor disease or, in $11.6 \%$, with an autoimmune disease. In $33.5 \%$ of the cases, bleeding was recognized too late as AHA. Our patient underwent multiple surgeries with a hemorrhagic origin without establishing the diagnosis of AHA.

The German Society for Thrombosis and Hemostasis Research (GTH) established a database in January 2010 to collect all data related to AHA. Besides the significant impact of immunosuppressive treatment for eradicating the inhibitor [4,5], a statement concerning the safety and efficacy of coagulation management could be made [6]. Furthermore, Holstein states that a weekly FVIII assessment would benefit the patient [7].

The cause of AHA is still unknown. However, there are some correlations with malignant tumors (6-18\%), autoimmune disease (9-17\%), and pregnancy (rate unknown) [8]. Around $68 \%$ of the bleeding occurs spontaneously. In most cases, life-threatening bleeding occurs with a mortality of $20 \%$ [9]. 


\subsection{Diagnostic}

Cases of isolated aPTT prolongation that coincide with bleeding should be investigated as AHA. Cases of antiphospholipid syndrome (APLS), which also show a prolonged aPTT, should be ruled out. In contrast to AHA, APLS is characterized by thrombosis rather than bleeding [8]. In addition, specific antibodies are found against different phospholipids (Cardiolipin, Pro-thrombin) and Phospholipid-binding proteins such as beta-2-Glycoprotein I, which increase the risk of thrombosis [10]. Diagnostic accuracy for APLS is based on lupusanticoagulant (LA) detection. LA antibodies against thrombin and beta-2-glycoprotein compete with the plasma coagulation factors for the binding sites on the phospholipids, which prompts a prolonged aPTT in vitro, although hypercoagulopathy is present [11].

In case of bleeding with an isolated aPTT prolongation, an individual factor determination should be carried out, simultaneously quantifying the inhibitor with the Bethesda assay. The inhibitors are antibodies directed against FVIII. The level of the antibody is given in Bethesda units (BU). The detection of the antibody in connection with the reduced FVIII activity $(<5 \%)$ confirms the diagnosis of AHA [6]. There is no correlation between inhibitor serum concentration and bleeding. However, lower levels of antibodies, e.g., $5 \mathrm{BE}$, may cause more severe bleeding than antibodies with higher serum levels (e.g., $15 \mathrm{BE}$ ).

\subsection{Discussion of AHA Treatment}

The treatment of AHA can be separated into four stages See Figure 3.

There are several agents available for bleeding control. The agents are stratified into "Bypass" agents and FVIII replacement agents.

\subsubsection{Factor VIII Replacement Treatment}

Factor VIII agents are effective when the FVIII inhibitor Titer is $\leq 5 \mathrm{BE}$ [12]. In cases where FVIII inhibitor Titer is $\leq 5 \mathrm{BE}$, the FVIII dose should be higher than when compared to inherited Hemophilia A. Higher doses cause effective suppression of the inhibitor, leading to sufficient FVIII activity to provide adequate hemostasis. The use of FVIII was successful in some patients with FVIII inhibitor Titer $\leq 5 \%$ and could be used as a first-line treatment. The recombinant porcine FVIII (rpFVIII; Obizur ${ }^{\circledR}$ ) represents an alternative to human FVIII preparations. The effectiveness was demonstrated in a study with a limited number of 28 patients [13]. Within $24 \mathrm{~h}$ of application of rpFVIII, all 28 patients showed FVIII serum activity $>$ than $100 \%$. In some cases, antibodies against rpFVIII are already present in serum or developed during treatment, making the routine assessment of these antibodies necessary before treatment or especially the response to $\mathrm{rPFVIII}$ is blunted. Therefore, the main advantage of rpFVIII agents compared to bypass treatment is the possibility of FVIII activity assessment.

\subsubsection{Bypass-Treatment}

Both rFVIIa and the activated prothrombin complex aPCC, (FEIBA (factor eight bypassing agent)) are suitable for AHA treatment [8]. The agent aPCC contains the vitamin K-dependent factors II, IX, and X, and the FVII, as activated factors, in contrast to PCC. Here the factors are inactivated and dissolved in heparin.

By administering these agents, propagation and amplification are skipped (see Figure 3), and a thrombin burst occurs directly (hence the term "bypassing agents"), which then activates fibrin formation. In the EACH-2 study [3], most patients were treated with rFVIIa (56.7\%), $20.5 \%$ of the patients received aPCC, FVIII agents were used in $18.2 \%$ of the cases, and $4.6 \%$ received Desmopressin-Vasopressin (DDAVP). The most effective treatment was observed with the "bypass preparations". Bleeding could successfully be controlled in $91.8 \%$ of the cases. There was no statistically significant difference between the two drugs preparations (rFVIIa, 91.8\% vs. 93.3\% FEI-BA). Replacement with FVIII was less effective than the two above-mentioned agents. Bleeding control was achieved in only $69.9 \%$. (For further details, see Table 1). For this reason, we preferred bypass therapy with rFVIIa (NovoSeven ${ }^{\circledR}$ ) for our patient. In our case, no other bleeding events were reported 
after hematoma evacuation and removal of the packed towels, further supporting our choice in hemostasis treatment.

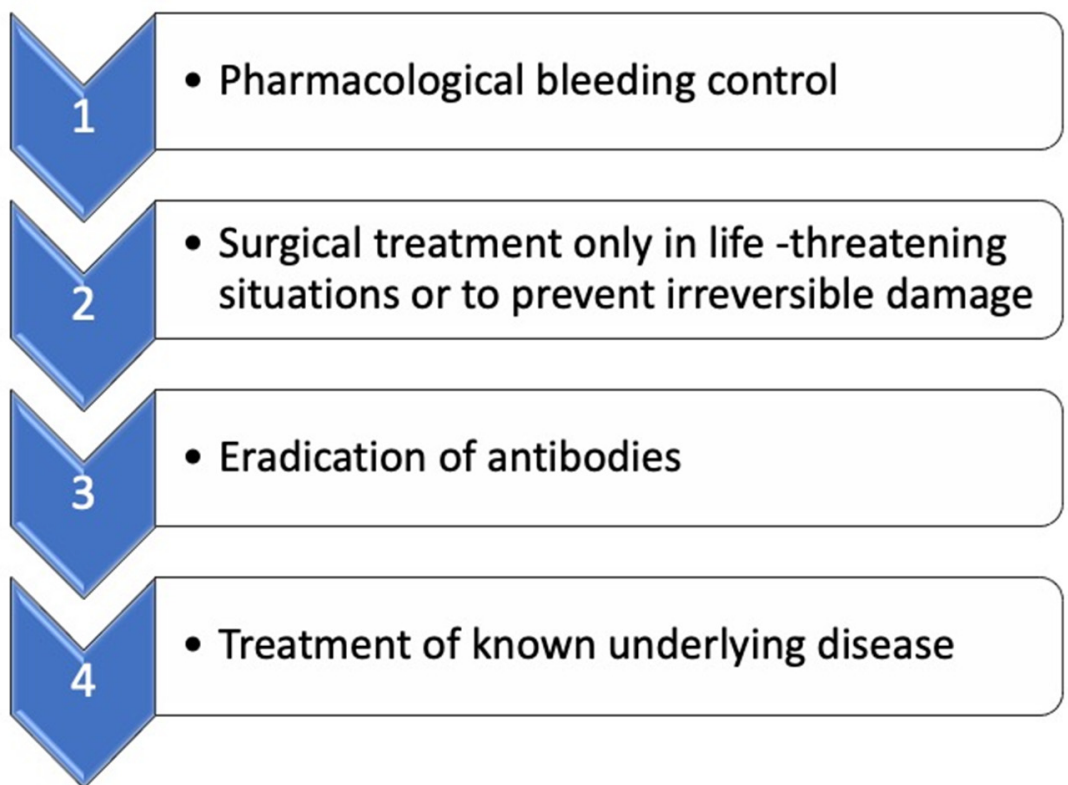

Figure 3. Acute treatment of bleeding. Modified according to Kruse-Jarres et al. [8].

Table 1. Drugs used to treat AHA-associated bleeding. Modified according to Kruse-Jarres et al. [8].

\begin{tabular}{lll}
\hline \multicolumn{1}{c}{ Agent } & \multicolumn{1}{c}{ Advantage } & \multicolumn{1}{c}{ Disadvantage } \\
\hline $\begin{array}{l}\text { rpFVIII (50-100 IU } / \mathrm{kg} \text { ); FVIII activity } \\
\text { assessment every } 3 \mathrm{~h} \text {. }\end{array}$ & & \\
$\begin{array}{l}\text { Assessment of Ab against rpFVIII => If } \\
\text { evident, increase the dose up to 200 } \\
\mathrm{IU} / \mathrm{kg}\end{array}$ & Serum levels of FVIII could be monitored & $\begin{array}{l}\text { Possible cross-reaction with } \\
\text { FVIII-inhibitors => less effectivity }\end{array}$ \\
\hline aPCC 50-100 IU $/ \mathrm{kg}$ every 8-12 h & $\begin{array}{l}\text { Always effective even at high levels of } \\
\text { AHA inhibitors }>10 \mathrm{BE}\end{array}$ & $\begin{array}{l}\text { No possible monitoring, thromboembolic } \\
\text { events are possible }\end{array}$ \\
\hline $\begin{array}{l}\text { rFVIIa 70-90 } \mu \mathrm{g} / \mathrm{kg} \text { every } 3 \mathrm{~h} \text { until } \\
\text { bleeding is stopped; then maintain the } \\
\text { dose and extend the intervals }\end{array}$ & $\begin{array}{l}\text { Always effective even at high levels of } \\
\text { AHA inhibitors }>10 \mathrm{BE}\end{array}$ & $\begin{array}{l}\text { No possible monitoring, thromboembolic } \\
\text { events are possible short half-life: } 2-3 \mathrm{~h}\end{array}$ \\
\hline
\end{tabular}

rpFVIII: recombinant porcine Factor VIII. aPCC: activated Prothrombincomplex. rFVIIa: recombinant activated Factor VII.

Recently, instead of bypass therapy, monoclonal antibodies, such as Emicizumab (Hemlibra ${ }^{\circledR}$ ) have been used [14]. Emiczumab is a recombinant, bispecific, monoclonal antibody that mimics the function of activated FVIII. Emicizumab binds with one side to the FIXa, the other side to the zymogen FX, and then activates the conversion of FX to F Xa. There is no structural relationship to FVIII, which prevents the formation of antibodies [15,16]. The drug has two decisive advantages. First, the possibility of subcutaneous application leads to extensive and independent use by the patient, which does not require medical consultation. The second very decisive advantage is the long half-life of 30 days, which makes the agent very attractive as a prophylactic preparation for patients with inherited Hemophilia A [17]. Thomas et al. conducted a scoping review on the use of emicizumab in AHA [18]. The authors reported on 33 AHA patients, from 12 studies. The patients presented with a wide range of bleeding symptoms: hematoma formation, mucocutaneous bleeds, and surgical site bleeds. Of these 33 patients, 26 received various methods of hemostasis treatment (rFVIIa, aPCC or rpFVIII). All patients achieved a clinical response to emicizumab with no further spontaneous bleeding. 
Further supporting hemostasis treatment is based on the increased release of FVIII and von Willebrand factor from the subendothelium. In some case reports, the use of TXA in combination with aPCC or rFVIIa was effective in increasing the clot strength $[19,20]$. From that point of view, TXA can be considered as a complementary therapy.

Treatment with aPCC or rFVIIa carries a significant risk of thromboembolic events. In the literature, the rate varies between $0 \%$ and $55 \%$. However, studies that recruited at least 100 patients report an incidence between 2.3\% and 2.9\% [21-23]. Besides a general propensity for thrombosis, factors such as immobility, presence of malignancy, previous thromboembolism, artificial valves, atrial fibrillation, and vascular stents may also contribute to a higher incidence of thrombosis [9].

\subsection{Inhibitor Eradication}

Although some older studies report spontaneous eradication of the inhibitor after several months [24], it is currently recommended that bypass therapy should be commenced simultaneously with eradication therapy [8]. The following three agents, corticosteroids, cyclophosphamide, and rituximab, work effectively for eradication (see Table 2). The median time of eradication was reported as 5 weeks. [8]. Patients who had an FVIII activity $<1 \%$ at the beginning of the therapy required a significantly longer treatment time for successfully eradicating the inhibitor than patients with FVIII activity of $>1 \%$.

Table 2. Drugs for eradication; modified according to Kruse-Jarres [8]

\begin{tabular}{|c|c|c|}
\hline Recommended Treatment & Dose & Comment \\
\hline Prednisone & $1 \mathrm{mg} / \mathrm{kg}$ p.o. 4 weeks & $\begin{array}{l}\text { Ineffective for patients with FVIII }<1 \% \text { and } \\
\text { inhibitor titer }>20 \mathrm{BE} \\
\text { Side effects: hyperglycemia, infections, } \\
\text { steroid psychosis }\end{array}$ \\
\hline Prednisone + Cyclophosphamide & $\begin{array}{l}\text { Prednisone } 1 \mathrm{mg} / \mathrm{kg} \\
\text { Cyclophosphamide: } 1-2 \mathrm{mg} / \mathrm{kg} \text { po daily or } \\
5 \mathrm{mg} / \mathrm{kg} \text { iv for } 4 \text { weeks }\end{array}$ & $\begin{array}{l}\text { May shorten the course of the disease } \\
\text { More side effects } \\
\text { Highest cure rate } \\
\text { Bone marrow toxic } \\
\text { (leukopenia/thrombopenia) }\end{array}$ \\
\hline Prednisone + Rituximab & $\begin{array}{l}\text { Prednisone } 1 \mathrm{mg} / \mathrm{kg} \\
\text { Rituximab } 375 \mathrm{mg} / \mathrm{m}^{2} \mathrm{iv} / \text { week for } 4 \text { weeks }\end{array}$ & $\begin{array}{l}\text { Rituximab is only recommended if the above } \\
\text { regimes have failed; Pneumococcal } \\
\text { vaccination recommended }\end{array}$ \\
\hline
\end{tabular}

In the EACH-2 study, 142 patients received steroids only, 83 patients received steroids and cyclophosphamide simultaneously, and 51 patients received steroids and rituximab simultaneously [25]. The highest remission rate with the shortest time to achieve remission was achieved using steroid plus cyclophosphamide combination (80\%, median 40 days). The second-best results were achieved with the steroid + rituximab combination (61\%, median 64 days). Steroid therapy alone resulted in remission in only 58\% of the cases, with a median time to remission of 32 days. Rituximab therapy alone was rare (12 patients) and had the lowest remissions at $42 \%$. A meta-analysis of 20 studies with 249 patients also concluded that the combination treatment of steroid + cyclophosphamide is superior to steroids alone [26]. Therefore, based on the available data, the authors favor treatment with steroids in combination with cyclophosphamide as first-line therapy.

Due to the mechanism of action of rituximab and the fact that B cells play an essential role in maintaining the immune response, rituximab therapy leads to an increased risk of developing infections. Patients undergoing rituximab therapy should receive a pneumococcal vaccine prior to therapy because of the possibility of iatrogenic B-cell depletion [27].

Cyclophosphamide leads to single and double strand breaks in rapidly dividing cells (bone marrow, mucous membranes), resulting in side effects such as leukopenia, thrombopenia, nausea, vomiting and hemorrhagic cystitis. Simultaneous administration of Mesna (mercaptoethanesulfonate sodium) is intended to prevent this side effect [28]. Since 
the dose of Cyclophosphoramide in our patient was significantly lower than in oncological patients, simultaneous protective therapy with Mesna was avoided. Hemorrhagic cystitis did not occur in our patient during the cyclophosphamide therapy.

\subsection{Do Patients with AHA and Bleeding Requires Thrombosis Prophylaxis?}

Due to the rarity of the disease, a general statement cannot be made. Data on thromboembolism appear to be inconsistent. In cohorts evaluating at least 100 patients, the incidence seems to be a maximum of 3\%. Experts recommend thrombosis prophylaxis with low molecular weight heparin, e.g., enoxaparin at $1 \mathrm{mg} / \mathrm{kg}$, as soon as the FVIII activity is $\geq 50 \%$. However, there are patient-predisposing factors for thrombosis, such as a history of thrombosis, pregnancy, or the presence of malignant diseases. In these patient groups, thrombosis prophylaxis at an earlier point in time may be considered. In our patient, thrombosis prophylaxis had already been initiated 1 week before the FVIII activity had reached $10 \%$ without any signs of bleeding.

\section{Conclusion for Daily Practice}

In the case of unexplainable atraumatic or recurrent bleeding after surgical therapy, a diagnosis of AHA should always be considered.

1. An isolated prolonged PTT value or prolonged clotting time in INTEM assay, with normal values in standard laboratory parameters or ROTEM (beside CT in INTEM), is suspicious for AHA. FVIII activity and possible inhibitors should be determined in these cases.

2. The standard of care is based on controlling the bleeding with mainly "bypass agents" and antibody eradication therapy.

3. Surgical therapy should only be considered for avoiding nerve compression, circulatory disorders, or other such emergency indications.

Author Contributions: Conceptualization, F.H.S. and K.M.N.; methodology, F.H.S. and A.C.; Formal analysis, C.S. and K.M.N. Investigation C.S. and F.H.S. writing-original draft preparation, F.H.S., K.M.N. and C.S. All authors have read and agreed to the published version of the manuscript.

Funding: This research received no external funding.

Institutional Review Board Statement: It is a case report with a review of the current literature. This single case was exempt from approval from an ethics' board.

Informed Consent Statement: Patients informed consent was waved due to single anonymized retrospective design.

Conflicts of Interest: F.H.S. has served as speaker for CSL Behring, Werfen, Biotest, Merz Pharmaceuticals.

\section{References}

1. Forces, A.D.T.; Ranieri, V.M.; Rubenfeld, G.D.; Thompson, B.T.; Ferguson, N.D.; Caldwell, E.; Fan, E.; Camporota, L.; Slutsky, A.S. Acute respiratory distress syndrome: The Berlin Definition. JAMA 2012, 307, 2526-2533.

2. Yee, T.T.; Griffioen, A.; A Sabin, C.; Dusheiko, G.; A Lee, C. The natural history of HCV in a cohort of haemophilic patients infected between 1961 and 1985. Gut 2000, 47, 845-851. [CrossRef]

3. Knoebl, P.; Marco, P.; Baudo, F.; Collins, P.; Huth-Kühne, A.; Nemes, L.; Pellegrini, F.; Tengborn, L.; Lévesque, H. Demographic and clinical data in acquired hemophilia A: Results from the European Acquired Haemophilia Registry (EACH2). J. Thromb. Haemost. 2012, 10, 622-631. [CrossRef] [PubMed]

4. Tiede, A.; Hofbauer, C.J.; Werwitzke, S.; Knobl, P.; Gottstein, S.; Scharf, R.E.; Heinz, J.; Gross, J.; Holstein, K.; Dobbelstein, C.; et al. Anti-factor VIII IgA as a potential marker of poor prognosis in acquired hemophilia A: Results from the GTH-AH 01/2010 study. Blood 2016, 127, 2289-2297. [CrossRef] [PubMed]

5. Tiede, A.; Klamroth, R.; Scharf, R.E.; Trappe, R.U.; Holstein, K.; Huth-Kuhne, A.; Gottstein, S.; Geisen, U.; Schenk, J.; Scholz, U.; et al. Prognostic factors for remission of and survival in acquired hemophilia A (AHA): Results from the GTH-AH 01/2010 study. Blood 2015, 125, 1091-1097. [CrossRef]

6. Werwitzke, S.; Geisen, U.; Nowak-Gottl, U.; Eichler, H.; Stephan, B.; Scholz, U.; Holstein, K.; Klamroth, R.; Knobl, P.; Huth-Kuhne, A.; et al. Diagnostic and prognostic value of factor VIII binding antibodies in acquired hemophilia A: Data from the GTH-AH 01/2010 study. J. Thromb. Haemost. 2016, 14, 940-947. [CrossRef] 
7. Holstein, K.; Liu, X.; Smith, A.; Knobl, P.; Klamroth, R.; Geisen, U.; Eichler, H.; Miesbach, W.; Tiede, A. Bleeding and response to hemostatic therapy in acquired hemophilia A: Results from the GTH-AH 01/2010 study. Blood 2020, 136, 279-287. [CrossRef]

8. Kruse-Jarres, R.; Kempton, C.L.; Baudo, F.; Collins, P.W.; Knoebl, P.; Leissinger, C.A.; Tiede, A.; Kessler, C.M. Acquired hemophilia A: Updated review of evidence and treatment guidance. Am. J. Hematol. 2017, 92, 695-705. [CrossRef]

9. Baudo, F.; Collins, P.; Huth-Kühne, A.; Lévesque, H.; Marco, P.; Nemes, L.; Pellegrini, F.; Tengborn, L.; Knoebl, P. Management of bleeding in acquired hemophilia A: Results from the European Acquired Haemophilia (EACH2) Registry. Blood 2012, 120, 39-46. [CrossRef]

10. Miyakis, S.; Lockshin, M.D.; Atsumi, T.; Branch, D.W.; Brey, R.L.; Cervera, R.; Derksen, R.H.W.M.; De Groot, P.G.; Koike, T.; Meroni, P.L.; et al. International consensus statement on an update of the classification criteria for definite antiphospholipid syndrome (APS). J. Thromb. Haemost. 2006, 4, 295-306. [CrossRef]

11. Greaves, M.; Cohen, H.; Machin, S.J.; Mackie, I. Guidelines on The Investigation and Management of The Antiphospholipid Syndrome. Br. J. Haematol. 2000, 109, 704-715. [CrossRef] [PubMed]

12. Nemes, L.; Pitlik, E. New protocol for immune tolerance induction in acquired hemophilia. Haematologica 2000, 85, 64-68. [PubMed]

13. Kruse-Jarres, R.; St-Louis, J.; Greist, A.; Shapiro, A.; Smith, H.; Chowdary, P.; Drebes, A.; Gomperts, E.; Bourgeois, C.; Mo, M.; et al. Efficacy and safety of OBI-1, an antihaemophilic factor VIII (recombinant), porcine sequence, in subjects with acquired haemophilia A. Haemophilia 2015, 21, 162-170. [CrossRef]

14. Mannucci, P.M. Hemophilia therapy: The future has begun. Haematologica 2020, 105, 545-553. [CrossRef] [PubMed]

15. Kitazawa, T.; Igawa, T.; Sampei, Z.; Muto, A.; Kojima, T.; Soeda, T.; Yoshihashi, K.; Okuyama-Nishida, Y.; Saito, H.; Tsunoda, H.; et al. A bispecific antibody to factors IXa and X restores factor VIII hemostatic activity in a hemophilia A model. Nat. Med. 2012, 18, 1570-1574. [CrossRef]

16. Shima, M.; Hanabusa, H.; Taki, M.; Matsushita, T.; Sato, T.; Fukutake, K.; Fukazawa, N.; Yoneyama, K.; Yoshida, H.; Nogami, K. Factor VIII-Mimetic Function of Humanized Bispecific Antibody in Hemophilia A. N. Engl. J. Med. 2016, 374, $2044-2053$. [CrossRef]

17. Uchida, N.; Sambe, T.; Yoneyama, K.; Fukazawa, N.; Kawanishi, T.; Kobayashi, S.; Shima, M. A first-in-human phase 1 study of ACE910, a novel factor VIII-mimetic bispecific antibody, in healthy subjects. Blood 2016, 127, 1633-1641. [CrossRef]

18. Thomas, V.M.; Abou-Ismail, M.Y.; Lim, M.Y. Off-label use of emicizumab in persons with acquired haemophilia A and von Willebrand disease: A scoping review of the literature. Haemophilia 2021, 28, 4-17. [CrossRef]

19. Hvas, A.-M.; Sørensen, H.T.; Norengaard, L.; Christiansen, K.; Ingerslev, J.; Sørensen, B. Tranexamic acid combined with recombinant factor VIII increases clot resistance to accelerated fibrinolysis in severe hemophilia A. J. Thromb. Haemost. 2007, 5, 2408-2414. [CrossRef]

20. Tran, H.T.T.; Sørensen, B.; Rea, C.J.; Bjørnsen, S.; Ueland, T.; Pripp, A.H.; Tjønnfjord, G.E.; Holme, P.A. Tranexamic acid as adjunct therapy to bypassing agents in haemophilia A patients with inhibitors. Haemophilia 2013, 20, 369-375. [CrossRef]

21. Sumner, M.J.; Geldziler, B.D.; Pedersen, M.; Seremetis, S. Treatment of acquired haemophilia with recombinant activated FVII: A critical appraisal. Haemophilia 2007, 13, 451-461. [CrossRef] [PubMed]

22. Ingerslev, J.; Sørensen, B. Parallel use of by-passing agents in haemophilia with inhibitors: A critical review. Br. J. Haematol. 2011, 155, 256-262. [CrossRef] [PubMed]

23. Amano, K.; Seita, I.; Higasa, S.; Sawada, A.; Kuwahara, M.; Shima, M. Treatment of acute bleeding in acquired haemophilia A with recombinant activated factor VII: Analysis of 10-year Japanese postmarketing surveillance data. Haemophilia 2016, 23, 50-58. [CrossRef] [PubMed]

24. Green, D.; Lechner, K. A survey of 215 non-hemophilic patients with inhibitors to Factor VIII. Thromb. Haemost. 1981, 45, 200-203. [CrossRef]

25. Collins, P.; Baudo, F.; Knoebl, P.; Lévesque, H.; Nemes, L.; Pellegrini, F.; Marco, P.; Tengborn, L.; Huth-Kühne, A. Immunosuppression for acquired hemophilia A: Results from the European Acquired Haemophilia Registry (EACH2). Blood 2012, 120 , 47-55. [CrossRef] [PubMed]

26. Delgado, J.; Jiménez-Yuste, V.; Hernandez-Navarro, F.; Villar, A. Acquired Haemophilia: Review and Meta-Analysis Focused on Therapy and Prognostic Factors. Br. J. Haematol. 2003, 121, 21-35. [CrossRef] [PubMed]

27. Impfkommission, S. Wissenschaftliche Begrundung fur die Aktualisierung der Empfehlungen zur Indikationsimpfung gegen Pneumokokken fur Risikogruppen. Epidemiol. Bull. 2016, 37, 385-406.

28. Monach, P.A.; Arnold, L.M.; Merkel, P.A. Incidence and prevention of bladder toxicity from cyclophosphamide in the treatment of rheumatic diseases: A data-driven review. Arthritis Care Res. 2010, 62, 9-21. [CrossRef] 